Article

\title{
An Evaluation of Different 3D Cultivation Models on Expression Profiles of Human Periodontal Ligament Fibroblasts with Compressive Strain
}

\author{
Agnes Schröder ${ }^{1} \mathbb{D}$, Ricarda Schöniger ${ }^{1}$, Juliane Oeldemann ${ }^{1}$, Gerrit Spanier ${ }^{2} \mathbb{D}$, Peter Proff $^{1}$, Jonathan Jantsch ${ }^{3}$, \\ Christian Kirschneck ${ }^{1, *,+}$ (iD) and Niklas Ullrich $1, *,+$
}

check for

updates

Citation: Schröder, A.; Schöniger, R.; Oeldemann, J.; Spanier, G.; Proff, P.; Jantsch, J.; Kirschneck, C.; Ullrich, N. An Evaluation of Different 3D Cultivation Models on Expression Profiles of Human Periodontal Ligament Fibroblasts with Compressive Strain. Int. J. Mol. Sci. 2022, 23, 2029. https://doi.org/ $10.3390 /$ ijms23042029

Academic Editor: Mirko Manetti

Received: 13 January 2022

Accepted: 8 February 2022

Published: 12 February 2022

Publisher's Note: MDPI stays neutral with regard to jurisdictional claims in published maps and institutional affiliations.

Copyright: (C) 2022 by the authors. Licensee MDPI, Basel, Switzerland. This article is an open access article distributed under the terms and conditions of the Creative Commons Attribution (CC BY) license (https:// creativecommons.org/licenses/by/ $4.0 /)$
1 Department of Orthodontics, University Medical Centre of Regensburg, 93053 Regensburg, Germany; agnes.schroeder@ukr.de (A.S.); ricarda.schoeniger@stud.uni-regensburg.de (R.S.); juliane.oeldemann@stud.uni-regensburg.de (J.O.); peter.proff@ukr.de (P.P.)

2 Department of Oral and Maxillofacial Surgery, University Medical Centre of Regensburg, 93053 Regensburg, Germany; gerrit.spanier@ukr.de

3 Department of Medical Microbiology and Hygiene, University Medical Centre of Regensburg, 93053 Regensburg, Germany; jonathan.jantsch@ukr.de

* Correspondence: christian.kirschneck@ukr.de (C.K.); niklas.ullrich@ukr.de (N.U.)

+ These authors contributed equally to this work.

Abstract: The effects of compressive strain during orthodontic treatment on gene expression profiles of periodontal ligament fibroblasts (PDLFs) have mostly been studied in 2D cell culture. However, cells behave differently in many aspects in 3D culture. Therefore, the effect of pressure application on PDLFs in different 3D structures was investigated. PDLFs were either conventionally seeded or embedded into different 3D structures (spheroids, Mebiol ${ }^{\circledR}$ gel, 3D scaffolds) and exposed to compressive force or incubated without pressure. For one 3D scaffold (POR), we also tested the effect of different compressive forces and application times. Expression of an angiogenic gene (VEGF), a gene involved in extracellular matrix synthesis (COL1A2), inflammatory genes (IL6, PTGS2), and genes involved in bone remodelling $(O P G, R A N K L)$ were investigated by RT-qPCR. Depending on the used 3D cell culture model, we detected different effects of compressive strain on expression profiles of PDLFs. COL1A2 was downregulated in all investigated 3D culture models. Angiogenetic and proinflammatory genes were regulated differentially between models. In 3D scaffolds, regulation of bone-remodelling genes upon compressive force was contrary to that observed in 3D gels. 3D cell culture models provide better approximations to in vivo physiology, compared with conventional 2D models. However, it is crucial which 3D structures are used, as these showed diverse effects on the expression profiles of PDLFs during mechanical strain.

Keywords: 3D cell culture; fibroblasts; PDLF; periodontal ligament; orthodontics; pressure; tooth movement

\section{Introduction}

The dental discipline of orthodontics deals with the diagnosis, prevention, and treatment of malocclusions, which are of aberrant jaw and tooth positions in relation to the skull and the jawbone. The aim of orthodontic treatment is to create a stable and functional occlusion for the patient [1]. According to epidemiological studies, at least $70 \%$ of the population are affected by some form of malocclusion [2], which can be associated with a variety of complaints and secondary conditions such as psychological distress and functional discomfort in chewing, swallowing, and speaking [1]. Affected patients have an increased susceptibility to dental trauma [3], and misaligned teeth can impair oral hygiene favouring carious lesions [4] and, in the long term, periodontitis [5]. A pathological inflammation of the periodontium can lead to tooth loss in the long term and is associated with an increased risk of coronary heart disease [6]. For this reason, orthodontic treatment 
of malocclusions is considered to have an important preventive and curative effect. Due to its biomechanical properties, the periodontal ligament (PDL) connecting the tooth to its surrounding alveolar bone acts as a physiological mediator during orthodontic therapy and ensures that the effect of an orthodontic force is evenly distributed to the surrounding tissues [7]. Basically, orthodontic tooth movement is the result of pressure and tension zones created by force application within the periodontal ligament: New bone formation occurs at tension zones during orthodontic therapy, while resorption of the adjacent alveolar bone occurs at pressure zones of the PDL [8]. Of particular importance are periodontal ligament fibroblasts (PDLFs), which express more of the receptor activator of NF-kB ligand $(R A N K L)$ upon compression and, thus, increase the differentiation of osteoclasts, which are crucial for bone remodelling processes [9]. Healthy periodontal ligament consists of various cell populations such as endothelial cells, remnants of Malassez epithelial cells, immune cells, and cells associated with the sensory system, as well as bone and cementum-forming cells [10]. However, by far, the most abundant and functionally important cell type of periodontal connective tissue is the fibroblast [11]. This cell type plays a central role in the maintenance of physiological functions of the periodontal ligament [12], but also in the repair and regeneration processes of periodontal structures [13]. When an orthodontic force is applied to the PDL, there is an increased local release of neurotransmitters, cytokines, or even growth factors $[9,14]$.The expression of inflammatory, vascular, and bone-modulating mediators triggers remodelling processes in the periodontal ligament and the surrounding alveolar bone [15]. PDLFs respond to compression with a markedly increased secretion of prostaglandin-endoperoxide synthase-2 (PTGS2) and prostaglandin-E2. This leads to increased expression of RANKL, which induces and increases osteoclastogenesis [9]. The increased activity of osteoclasts [1] leads to increased bone resorption at the pressure side [16], which ultimately enables tooth movement towards the compressed areas [17]. On the traction side, on the other hand, stretching of the periodontal fibre bundles provides certain stimuli that lead to the formation of new bone [17]. Our current understanding of many cellular processes is largely based on studies of homogeneously growing populations of cell cultures cultivated linearly on plastic surfaces [18]. This two-dimensional cell culture system is considered the gold standard for studying all cell types [19]. Advances in tissue engineering now enable three-dimensional cultivation and, thus, the mimicking of more realistic biochemical and biomechanical microenvironments for the cells under investigation [20]. These cultivation models ultimately approximate the in vivo situation of the human organism much better than it is the case with 2D cell cultures [21]. It is interesting to note that the gene expression of cells behaves differently in three-dimensional cultivation than in two-dimensional cultivation [21,22]. In their studies, Brezulier et al. (2020) were also able to demonstrate that PDLFs grown as spheroid culture in three dimensions show different reactions to mechanical strain than the same cell type after two-dimensional cultivation [23]. Thus, the question arises, to which extent the knowledge gained so far on $2 \mathrm{D}$ models regarding the response of PDLFs to mechanical forces in orthodontics corresponds to the physiology of the human organism and the actual response of PDLFs in the local tissue. Although the effect of three-dimensional cultivation has already been investigated, this study is the first to show a comparison of the expression patterns of PDLFs with a focus on OTM in different three-dimensional cell cultures under mechanical stress. The aim of this study is to identify the most suitable 3D culture model for future experiments on mechanically strained PDLF.

\section{Results}

2.1. Impact of Pressure Application on PDLFs Cultivated as Monolayers in Hydrogel, as Spheroids, or as Spheroids Embedded in Hydrogel

First, we determined the expression of the angiogenetic gene vascular endothelial growth factor (VEGF, Figure 1a,b). A significant increase in VEGF gene expression in standard 2D cell culture was detected after the application of compressive strain $(p=0.003$; 
Figure 1a). Cultivation of single cells in hydrogels resulted in increased VEGF gene expression $(p=0.008)$, without further effect by pressure application $(p>0.999)$.
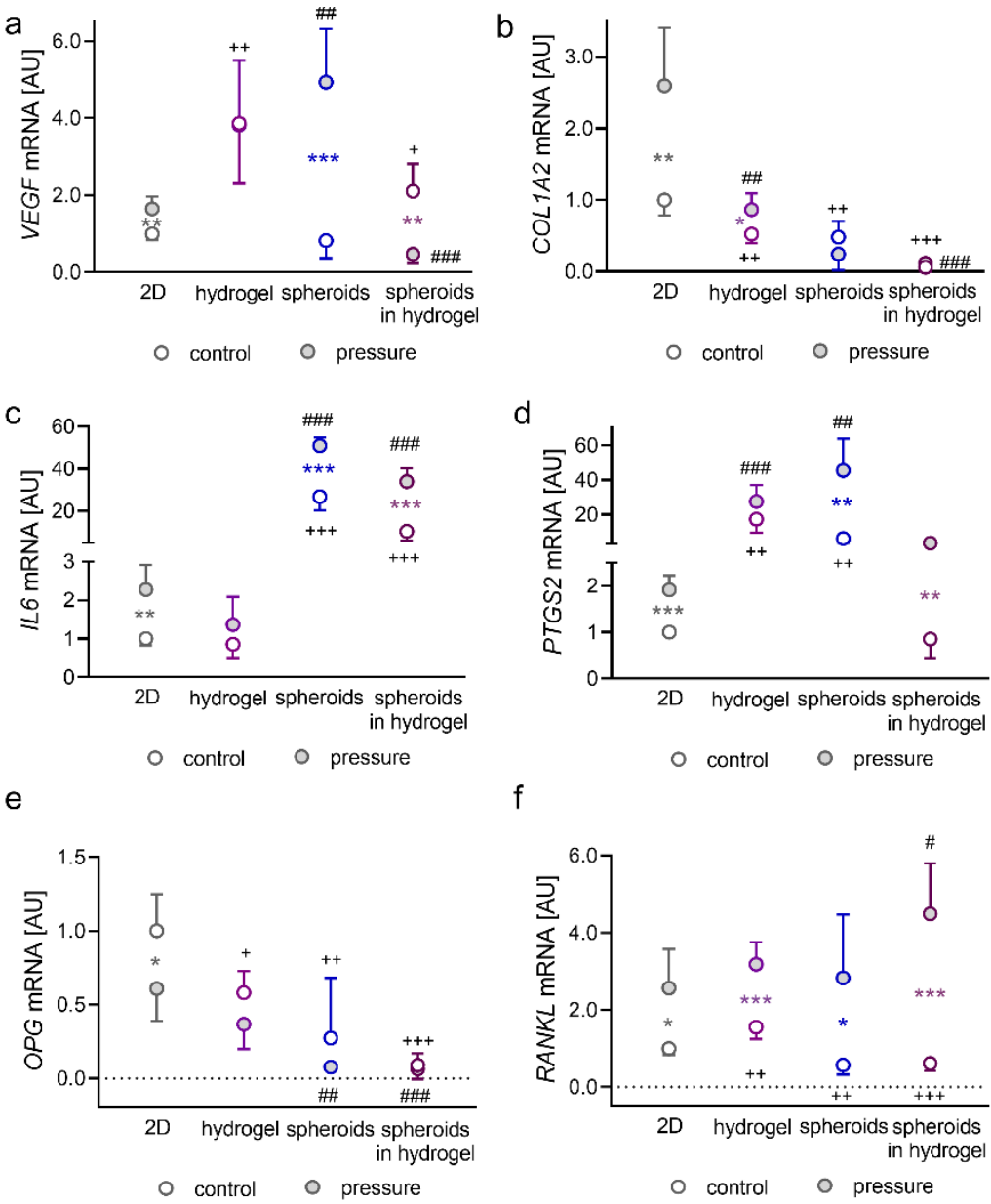

Figure 1. Impact of cultivation in hydrogels on the expression profiles of PDLFs cultured as monolayers or spheroids on the gene expression of VEGF (a), COL1A2 (b), IL6 (c), PTGS2 (d), OPG (e), and RANKL (f); $n=9$; Symbols represent mean values and the vertical lines show the standard deviation. Statistics: Welch-corrected ANOVA with Games-Howell multiple comparison tests. ${ }^{*}$ pressure effect: ${ }^{*} p<0.05,{ }^{* *} p<0.01,{ }^{* * *} p<0.001{ }^{+}{ }^{+}$cultivation effect without compression: ${ }^{+} p<0.05,{ }^{++} p<0.01$, ${ }^{+++} p<0.001$; ${ }^{+}$cultivation effect in combination with compression: ${ }^{\# \#} p<0.01$, \#\#\# $p<0.001$.

VEGF mRNA quantity increased with compressive strain in PDLFs formed to spheroids $(p<0.001$; Figure 1a). However, embedded-in-hydrogel PDLF spheroids showed a downregulation of VEGF expression under pressure $(p=0.001$; Figure 1a). Collagen-1-alpha-2 (COL1A2) encodes for a subunit of collagen fibrils and is, therefore, essential for extracellular matrix remodelling. COL1A2 gene expression by PDLFs was upregulated by compressive strain in 2D culture $(p=0.004)$ and when embedded in hydrogel ( $p=0.026$; Figure $1 c)$. This pressure effect disappeared when PDLFs were formed to spheroids ( $p=0.368$ and spheroids in hydrogel: $p=0.972$ ). Cultivation of PDLFs in hydrogel reduced COL1A2 mRNA expression without $(p=0.001)$ and with compressive strain $(p=0.002)$. This was also the case in the spheroid group (control: $p=0.002$; pressure: $p<0.001$ ) and the spheroids-in-hydrogel group (control: $p<0.001$; pressure: $p<0.001$; Figure 1b). During orthodontic tooth movement, a pseudoinflammation occurs with increased release and expression of inflammatory factors. Therefore, we tested the effect of different cultivation types on the gene expression of interleukin-6 (IL6) and prostaglandin-endoperoxide synthase-2 (PTGS2; Figure 1c,d). Compressive strain increased IL6 mRNA expression in 2D culture $(p=0.018)$, in spheroids and 
in spheroids embedded in hydrogel $(p<0.001)$ but not in single cells in hydrogel $(p=0.578$; Figure 1c). Notably, spheroid formation massively increased IL6 gene expression without and with pressure application $(p<0.001$; Figure 1c). Next to IL6 mRNA, PTGS2 gene expression was elevated with compressive strain in 2D culture $(p<0.001)$, in spheroids $(p=0.003)$ and in spheroids in hydrogel ( $p=0.003$; Figure $1 \mathrm{~d})$. We detected a significant increase in PTGS2 mRNA in hydrogel (control: $p=0.003$; pressure: $p<0.001$ ) and after spheroids were formed (control: $p=0.005$; pressure: $p=0.001$ ). This effect was truncated when spheroids were embedded in hydrogel (control: $p=0.953$; pressure: $p=0.066$; Figure 1d). Lastly, we investigated the expression of genes involved in bone remodelling. Osteoprotegerin (OPG) gene expression was only reduced in 2D culture by compressive strain $(p=0.043$; Figure $1 \mathrm{e})$. However, overall OPG mRNA expression quantity was lower in all tested 3D cultures without (hydrogel: $p=0.013$, spheroids: $p=0.009$; spheroids in hydrogel: $p<0.001$ ) and with compressive strain (hydrogel: $p=0.222$, spheroids: $p=0.001$; spheroids in hydrogel: $p<0.001$; Figure 1e). Gene expression of receptor activator of NF-kB ligand $(R A N K L)$ was upregulated in all investigated setups (2D: $p=0.020$, hydrogel: $p<0.001$, spheroids: $p=0.040$; spheroids in hydrogel: $p<0.001$; Figure 1f). RANKL was increased under control conditions in hydrogel $(p=0.008)$, whereas it was reduced in spheroids $(p=0.013$; spheroids in hydrogel: $p=0.005)$. Embedding spheroids in hydrogel even increased $R A N K L$ gene expression with compressive strain ( $p=0.050$; Figure 1f). Pressure application significantly elevated lactatdehydrogenase (LDH) release by PDLFs under compression in all cultivation models. There was no significant difference in LDH expression levels between all forms of 3D cell culture and 2D cell culture (Supplementary Figure S1a).

\subsection{Impact of Pressure Application on PDLFs Cultivated in Different Solid 3D Scaffolds}

Next, it was our goal to determine the possible effects of different solid 3D scaffolds on the expression profiles of PDLFs without and with compressive force application. Expression of the angiogenic gene VEGF was elevated in conventional 2D cell culture after compressive strain ( $p=0.025$; Figure $2 \mathrm{a})$.

In contrast, the compressive strain showed no effect on VEGF expression in all of the investigated solid 3D scaffolds $(p>0.99)$. COL1A2 gene expression was upregulated with compressive strain in the 2D model ( $p<0.001$; Figure 2b). Cultivation of PDLFs in 3D scaffolds reduced COL1A2 gene expression in general without any effect by compression $(p<0.001$; Figure $2 b)$. The expression of the inflammatory gene IL 6 was elevated with compressive strain in 2D cell culture $(p<0.001), \mathrm{NF}(p=0.004)$, and POR scaffold $(p=0.040$; Figure 2c). In the mixed NF/MF and the MF scaffold, no pressure effect on IL6 gene expression was detectable $(p=0.997)$. In general, compressive induction of IL6 was significantly reduced in the 3D scaffolds, compared with the 2D control $(p<0.001$; Figure 2c). As expected, gene expression of PTGS2 was upregulated in all tested cultivation models (2D: $p=0.033$; NF: $p=0.001$; NF/MF: $p=0.004$; MF: $p=0.010$; POR: $p=0.015$; Figure 2d). Contrary to IL6 gene expression, the pressure effect on PTGS2 gene upregulation was even higher in the tested 3D scaffolds, compared with 2D cultivation (NF: $p=0.003$; NF/MF: $p=0.004$; MF: $p=0.011$; POR: $p=0.015)$. Gene expression of the RANKL decoy receptor OPG was upregulated in the mixed NF/MF $(p=0.011), \operatorname{MF}(p=0.025)$, and POR scaffold ( $p<0.001$; Figure $2 \mathrm{e}$ ) with compressive force. The amount of expressed $R A N K L$ was reduced in general in all 3D scaffolds examined, compared with the 2D control, regardless of the stimulation by pressure application (Figure $2 \mathrm{f}$ ). A compressive upregulation of RANKL mRNA was significant in the 2D control $(p=0.007)$, NF $(p=0.009)$, and POR scaffold ( $p=0.004$; Figure $2 \mathrm{f}$ ). Measurement of LDH in the supernatant of the samples revealed a significantly higher LDH release by PDLFs under compressive strain regardless of the type of cultivation with the exception of the POR scaffold, which induced a slightly higher LDH release already without pressure application, compared with the 2D control (Supplementary Figure S1b). 

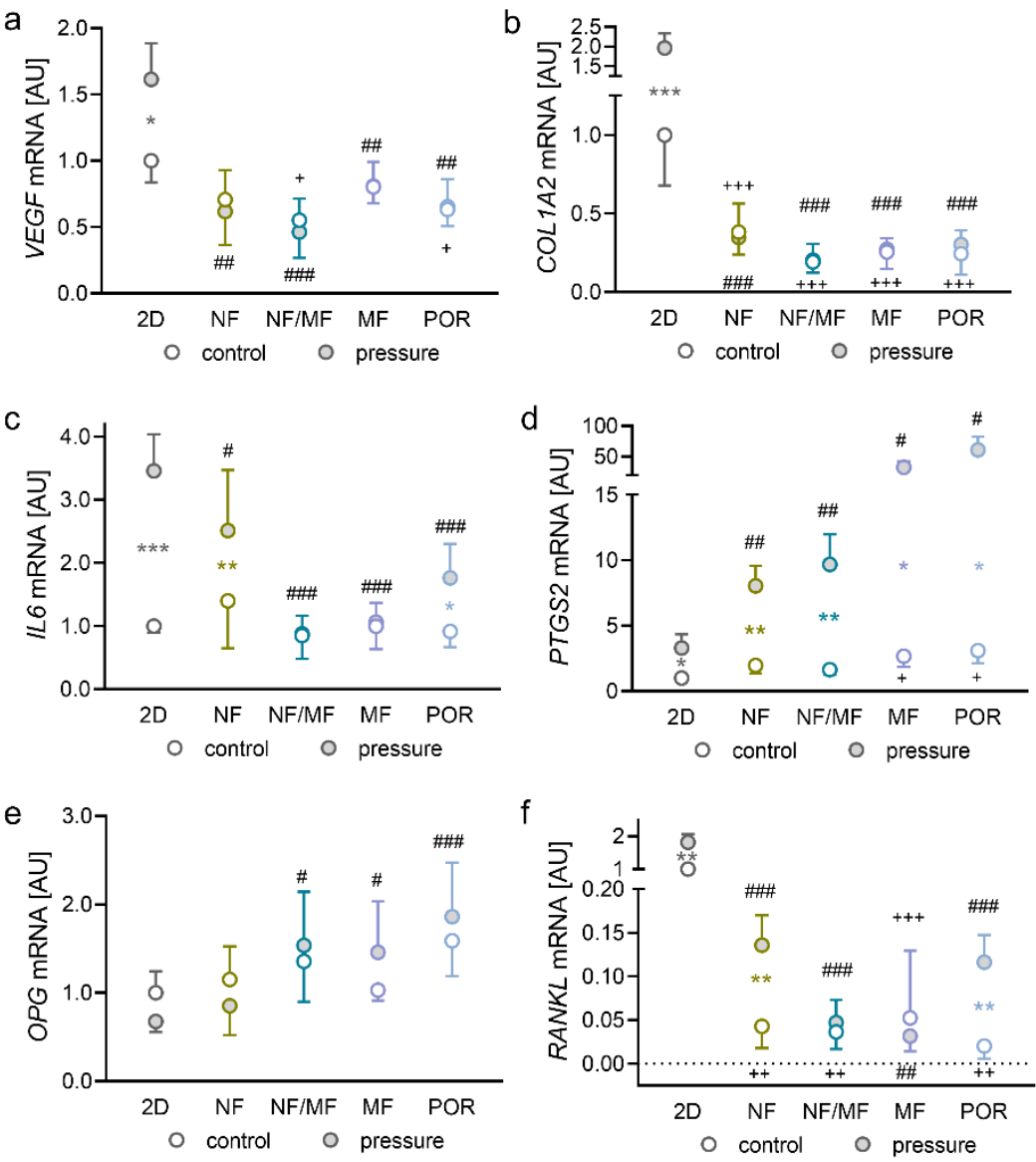

Figure 2. Impact of cultivation in different 3D scaffolds on the gene expression of VEGF (a), COL1A2 (b), IL6 (c), PTGS2 (d), OPG (e), and RANKL (f); $n=6$; symbols represent mean values and the vertical lines show the standard deviation. Statistics: ordinary ANOVA with Holm-Sidak's multiple comparison tests (COL1A2, IL6, OPG) or Welch-corrected ANOVA with Games-Howell multiple comparison tests (VEGF, PTGS2, RANKL). ${ }^{*}$ pressure effect: ${ }^{*} p<0.05,{ }^{* *} p<0.01,{ }^{* * *} p<0.001$; ${ }^{+}$cultivation effect without compression: ${ }^{+} p<0.05,{ }^{++} p<0.01,{ }^{+++} p<0.001$; ${ }^{\#}$ cultivation effect in combination with compression: ${ }^{\#} p<0.05,{ }^{\# \#} p<0.01$, \#\#\# $p<0.001$.

2.3. Impact of Different Magnitudes of Compressive Force on the Expression Profiles of PDLFs in the POR Scaffold

In this experiment, we compared the effects of different magnitudes of compressive force in the conventional 2D model and in the POR scaffold. To this end, we used $\mathrm{ZnO}_{2}$ plates, which applied $2 \mathrm{~g} / \mathrm{cm}^{2}, 4 \mathrm{~g} / \mathrm{cm}^{2}$ or $6 \mathrm{~g} / \mathrm{cm}^{2}$ on the PDLFs. In the conventional 2D model, compression with $2 \mathrm{~g} / \mathrm{cm}^{2}(p=0.003)$ and $4 \mathrm{~g} / \mathrm{cm}^{2}(p=0.008)$ increased VEGF gene expression significantly (Figure $3 a)$. This effect was no longer detectable with a compressive force of $6 \mathrm{~g} / \mathrm{cm}^{2}(p=0.664)$. PDLFs cultured in the POR scaffold only showed an increase in VEGF gene expression after compression with $6 \mathrm{~g} / \mathrm{cm}^{2}(p=0.004)$ but not with $2 \mathrm{~g} / \mathrm{cm}^{2}(p=0.338)$ or $4 \mathrm{~g} / \mathrm{cm}^{2}(p=0.664)$, leading to a significant difference in VEGF gene expression between the $2 \mathrm{D}$ model and the POR scaffold with compressive forces of $2 \mathrm{~g} / \mathrm{cm}^{2}$ and $6 \mathrm{~g} / \mathrm{cm}^{2}(p<0.001$; Figure 3a). COL1A2 gene expression was already increased at a force of $2 \mathrm{~g} / \mathrm{cm}^{2}$ in $2 \mathrm{D}$ culture $(p=0.003)$, whereas significant upregulation of COL1A2 in the POR scaffold was only visible at $4 \mathrm{~g} / \mathrm{cm}^{2} .(p=0.047$; Figure $3 \mathrm{~b})$. Expression of the inflammatory gene IL6 was elevated in the 2D model with all tested compression forces $\left(2 \mathrm{~g} / \mathrm{cm}^{2}: p=0.003 ; 4 \mathrm{~g} / \mathrm{cm}^{2}: p<0.001 ; 6 \mathrm{~g} / \mathrm{cm}^{2}: p=0.005\right.$; Figure $\left.3 \mathrm{c}\right)$. For PDLFs cultured in the POR scaffold, we observed a significant increase in IL6 gene expression with all tested compression forces as well $\left(2 \mathrm{~g} / \mathrm{cm}^{2}: p=0.002 ; 4 \mathrm{~g} / \mathrm{cm}^{2}: p=0.045 ; 6 \mathrm{~g} / \mathrm{cm}^{2}: p=0.043\right)$. A force of $6 \mathrm{~g} / \mathrm{cm}^{2}$, however, boosted IL6 gene expression even further (Abb. 4c). Pressure 
application elevated PTGS2 gene expression in the 2D model and in the POR scaffold with $2 \mathrm{~g} / \mathrm{cm}^{2}$ (2D: $p=0.006$; POR: $\left.p=0.012\right)$ and $4 \mathrm{~g} / \mathrm{cm}^{2}$ (2D: $p=0.002 ;$ POR: $p=0.025$; Figure 3d). A compression force of $6 \mathrm{~g} / \mathrm{cm}^{2}$ increased PTGS2 gene expression of PDLFs cultured in the POR scaffold even further $(p<0.001)$, whereas there was no significant compression effect at this force level in the 2D group ( $p=0.087$; Figure 3d). Notably, PTGS2 gene expression was higher in all tested conditions in the POR scaffold, compared with the 2D model $\left(0 \mathrm{~g} / \mathrm{cm}^{2}: p=0.004 ; 2 \mathrm{~g} / \mathrm{cm}^{2}: p=0.003 ; 4 \mathrm{~g} / \mathrm{cm}^{2}: p=0.019 ; 6 \mathrm{~g} / \mathrm{cm}^{2}: p<0.001\right)$. This was similar for OPG gene expression, where we detected increased expression after all tested pressure magnitudes in the POR scaffold, compared with the 2D model $\left(2 \mathrm{~g} / \mathrm{cm}^{2}: p=0.002\right.$; $4 \mathrm{~g} / \mathrm{cm}^{2}: p=0.009 ; 6 \mathrm{~g} / \mathrm{cm}^{2}: p=0.044$; Figure 3e). In the conventional 2D model, gene expression of RANKL was elevated by compression with $2 \mathrm{~g} / \mathrm{cm}^{2}$ and $4 \mathrm{~g} / \mathrm{cm}^{2}(p<0.001)$ but not with $6 \mathrm{~g} / \mathrm{cm}^{2}$ ( $p=0.238$; Figure $\left.3 \mathrm{f}\right)$. Cultivation of PDLFs in the POR scaffold abolished the pressure effect significantly $\left(2 \mathrm{~g} / \mathrm{cm}^{2}: p=0.033 ; 4 \mathrm{~g} / \mathrm{cm}^{2}: p<0.001\right)$. Higher compressive forces resulted in higher LDH release, starting at a force of $2 \mathrm{~g} / \mathrm{cm}^{2}$ under $2 \mathrm{D}$ conditions and $6 \mathrm{~g} / \mathrm{cm}^{2}$ in the POR scaffolds (Supplementary Figure S1c). Therefore, a significant difference in LDH release between the 2D and POR-scaffold groups was only detectable without pressure application and with a force magnitude of $6 \mathrm{~g} / \mathrm{cm}^{2}$.
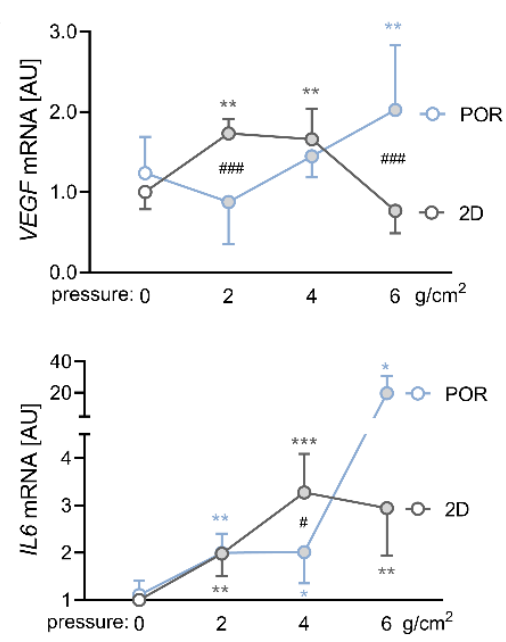

e

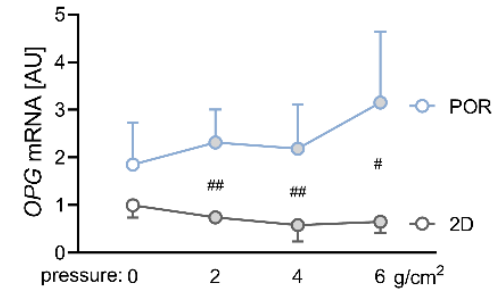

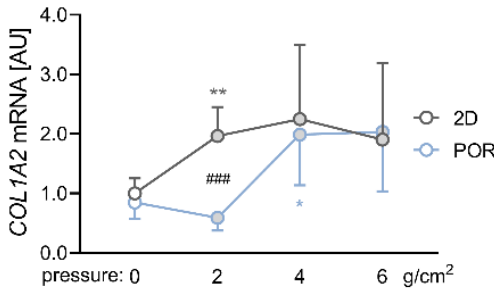

d
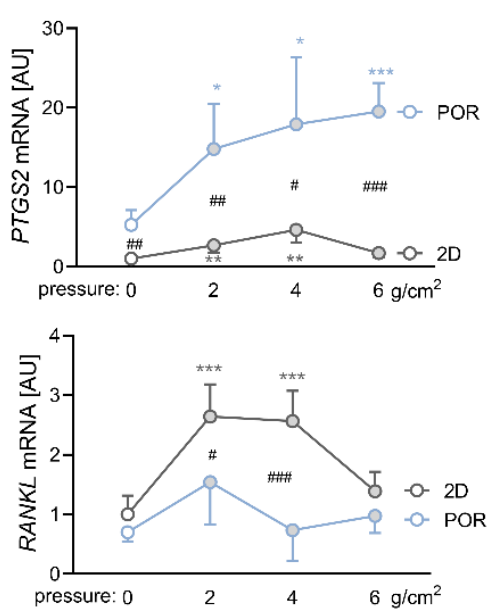

Figure 3. Impact of different compression forces on the gene expression of VEGF (a), COL1A2 (b), IL6 (c), PTGS2 (d), OPG (e), and RANKL (f) in PDLFs cultured in the POR scaffold; $n \geq 7$; symbols represent mean values and the vertical lines show the standard deviation. Statistics: Welch-corrected ANOVA with Games-Howell multiple comparison tests except for VEGF: ordinary ANOVA with Holm-Sidak's multiple comparison tests. ${ }^{*}$ pressure effect: ${ }^{*} p<0.05,{ }^{* *} p<0.01,{ }^{* * *} p<0.001$; \# cultivation effect: ${ }^{\#} p<0.05,{ }^{\# \#} p<0.01,{ }^{\# \# \#} p<0.001$.

\subsection{Impact of Different Compression Times on the Expression Profiles of PDLFs in the POR Scaffold}

Next, we compressed PDLFs cultivated in either conventional 2D culture or in the POR scaffold with $2 \mathrm{~g} / \mathrm{cm}^{2}$, for $4 \mathrm{~h}, 24 \mathrm{~h}, 48 \mathrm{~h}$, or $72 \mathrm{~h}$. VEGF gene expression showed a peak after $48 \mathrm{~h}$ of compressive strain in the 2D model $(p<0.001$; Figure $4 \mathrm{a})$, while PDLFs cultivated in the POR scaffold showed no significant compression effect on VEGF expression $(p \geq 0.99)$. Gene expression of COL1A2 was elevated in the $2 \mathrm{D}$ model after $24 \mathrm{~h}$ 
and 48 h of compressive strain ( $24 \mathrm{~h}: p=0.015 ; 48 \mathrm{~h}: p=0.014$; Figure $4 \mathrm{~b})$. Again, PDLFs did not increase COL1A2 mRNA expression in reaction to compressive strain, when they were cultivated in the POR scaffold ( $p \geq 0.999$ ). Notably, gene expression of COL1A2 was in general at a lower level, when PDLFs were cultured in the POR scaffold (Figure $4 \mathrm{~b}$ ). IL6 gene expression was elevated in the 2D model only after $48 \mathrm{~h}$ of compression ( $48 \mathrm{~h}$ : $p=0.035 ; 72$ h: $p<0.001$; Figure 4c). The same effect was apparent in the POR scaffold ( $48 \mathrm{~h}: p<0.001 ; 72 \mathrm{~h}: p=0.010$ ). After $72 \mathrm{~h}$ compression time, there was a significant increase in IL6 gene expression in PDLFs cultivated in the POR scaffold, compared with PDLFs cultivated in the 2D monolayer ( $p=0.016$; Figure 4c). PTGS2 gene expression was increased after $48 \mathrm{~h}$ of compression in the 2D model (48 h: $p=0.001 ; 72 \mathrm{~h}: p=0.032$; Figure 4d). In the POR scaffold, PTGS2 gene expression was at a higher level, compared with the 2D model ( $p<0.001$; Figure $4 \mathrm{~d}$ ). This was also the case for OPG gene expression, which was upregulated in PDLFs cultivated in the POR scaffold after compressive strain (Figure 4e). As expected, RANKL gene expression was elevated after $48 \mathrm{~h}$ of compressive strain, when PDLFs were cultivated in the conventional 2D model ( $p=0.004$; Figure $4 \mathrm{f})$. When cultivated in the POR scaffold, PDLFs showed reduced but significant compressive effects on RANKL upregulation after $48 \mathrm{~h}(p=0.041)$. Contrary to OPG gene expression, $R A N K L$ gene expression was significantly lower in the POR scaffold, compared with the 2D model at baseline $(0 \mathrm{~h}: p<0.001)$ and after $48 \mathrm{~h}(p<0.001)$ and $72 \mathrm{~h}$ of compression $(p=0.002$; Figure $4 \mathrm{f}$ ). From a compression period of $24 \mathrm{~h}$ and longer $\mathrm{LDH}$ levels increased in the 2D control, whereas PDLFs in the POR scaffold first showed reduced LDH values after $4 \mathrm{~h}$, before LDH levels significantly increased as well after $24 \mathrm{~h}$ (Supplementary Figure S1d).
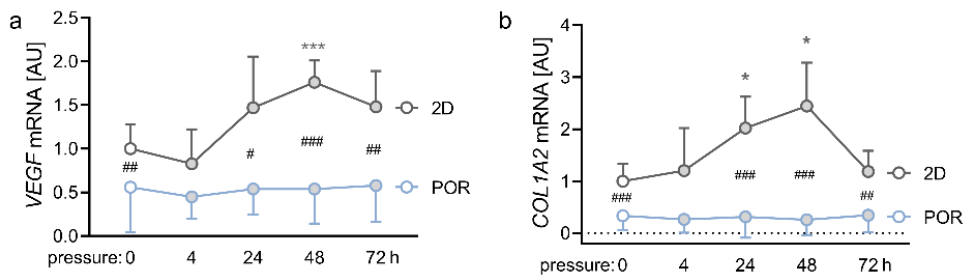

c

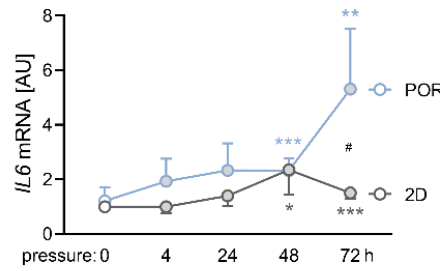

d
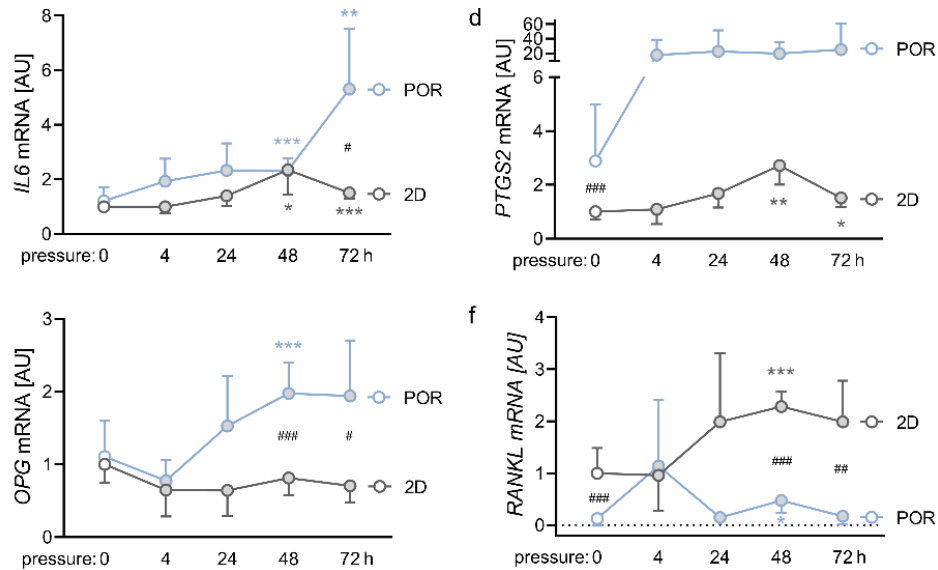

Figure 4. Impact of different compression times on the gene expression of VEGF (a), COL1A2 (b), IL6 (c), PTGS2 (d), OPG (e), and RANKL (f) in PDLFs cultured in the POR scaffold; $n \geq 7$; symbols represent mean values and the vertical lines show the standard deviation. Statistics: Welch-corrected ANOVA with Games-Howell multiple comparison tests. ${ }^{*}$ pressure effect: ${ }^{*} p<0.05,{ }^{* *} p<0.01$, *** $p<0.001$; ${ }^{*}$ cultivation effect: ${ }^{\#} p<0.05,{ }^{\# \#} p<0.01$, \#\#\# $p<0.001$.

\section{Discussion}

In this study, we determined the expression profiles of PDLFs subjected to mechanical strain in different three-dimensional environments, also to ultimately identify the most suitable 3D environment for future in vitro 3D experiments with PDLFs under mechanical strain. 
Thus far, it has been observed that the cell shape of adherent cells is completely altered in 2D culture compared with 3D culture media [24]. Furthermore, culturing cells under 2D conditions can result in a loss of cellular signalling pathways and changes in cell responses to certain stimuli $[20,25,26]$. Cells cultivated in 3D show a spatial distribution of cell-adhesion sites and a higher physical barrier of the surrounding matrix [27], so a three-dimensional matrix seems more accurate to correctly reproduce mechanical and biochemical cues in vitro [20,28]. The mechanical properties of the ECM hereby do not only affect the fibroblasts, but even more so, fibroblasts can also alter the mechanical properties of the ECM in an adequate three-dimensional environment [29]. Considering these aspects, three-dimensional cultivation seems crucial in the investigation of mechanotransduction in PDLFs.

To simulate compressive strain, ceramic discs with different weights were used. This uniform weight method is the most commonly used method for the investigation of orthodontic compressive strain on PDLFs [30]. As shown in a systematic review by Li et al., most studies used forces in the range between $1 \mathrm{~g} / \mathrm{cm}^{2}$ and $4 \mathrm{~g} / \mathrm{cm}^{2}$. Similar to our study, most studies in this review used a compressive force of $2 \mathrm{~g} / \mathrm{cm}^{2}$ [30]. This differs from the proposed orthodontic forces by Schwarz $\left(15-20 \mathrm{cN} / \mathrm{cm}^{2}\right)$, and stress in the periodontal ligament can reach values up to $120 \mathrm{~g} / \mathrm{cm}^{2}$ [30]. This is mainly due to the fact that we did not examine whole periodontal tissues with many cell lines in a complex extracellular matrix but a single cell line with the need for smaller forces. However, as PDLFs are embedded in a three-dimensional culture this time, it may be appropriate to increase disc weight, compared with 2D culture, as less compressive force may reach the individual cell in this experimental setup. For this reason, in addition to a $2 \mathrm{~g} / \mathrm{cm}^{2}$ force, $4 \mathrm{~g} / \mathrm{cm}^{2}$ and $6 \mathrm{~g} / \mathrm{cm}^{2}$ forces were also examined on a POR scaffold in this study.

As of today, there are many different types of 3D culture. Mainly used 3D environments are naturally derived matrices, synthetic hydrogel-based scaffolds, solid porous scaffolds, and spheroids [24,31,32]. Naturally derived matrices, such as collagen, fibrin, or other complex decellularised matrices show on the one hand good biochemical properties, but are mostly limited in design flexibility and show batch-to-batch variability influencing reproducibility of experiments [27,32]. Synthetic porous scaffolds and hydrogels do not show these problems and can be altered in their biochemical and mechanical properties [24]. For this reason, we decided to use Mebiol ${ }^{\circledR}$ Gel, a poly(ethylene glycol)-(PEG)-based hydrogel, and porous scaffolds on poly( $\varepsilon$-caprolactone) basis with different fibre morphologies. As a third option, we formed PDLFs to spheroids on low-adherent agarose. Compared with scaffold-based matrices such as hydrogels and solid scaffolds, the creation of spheroids is based on the basic principle of self-assembly, independent of biocompatible scaffold materials [20,33]. Thereby, the formation of the spheroid relies on intense cell-cell contacts and on the formation of their own extracellular matrix components [32-34]. In contrast to scaffold-based approaches, there is also a higher initial cell density [31] and a nutrient and waste gradient within the spheroid, resulting in high proliferative activity on the spheroid surface and necrotic cells in the core [20,33]. These morphologic aspects must be taken into account in the interpretation of the results. Finally, we embedded previously formed spheroids in $\mathrm{Mebiol}^{\circledR}$ hydrogel to alter the mechanical properties of the ECM and to counter the typical low stiffness of spheroids, since the mechanical properties of the ECM can itself affect the gene expression of cell lines [20,31].

The vascular endothelial growth factor (VEGF) is involved in the neoformation and vasodilation of blood vessels [15]. This growth factor is targeted by the transcription factor HIF-1 $\alpha$, which is mainly induced by hypoxia but can also be mechanically stabilised [35-37]. Thus, VEGF is important in the reorganisation of the periodontal ligament during orthodontic tooth movement [38]. In general, a higher level of VEGF either after pressure application or under control conditions was higher in hydrogel and spheroids. PDLFs embedded in hydrogel showed higher VEGF expression values in general, with no effect by mechanical strain. Higher stiffness of the artificial hydrogel with the associated higher mechanical barrier of the ECM may be one reason for reduced mechanotransductive VEGF expression of PDLFs in Mebiol ${ }^{\circledR}$ gel. The highest mechanotransductive induction of VEGF was seen in 
spheroids, followed by spheroids in hydrogels. The high VEGF induction by PDLFs formed to spheroids may be explained by the oxygen gradient present in spheroids [20,33]. Laschke et al. describe an upregulation of hypoxia-induced survival factors such as VEGF due to inefficient oxygen diffusion to cells in the core of spheroids [33]. In contrast, cultivation of PDLFs on solid 3D scaffolds showed in general lower levels of VEGF expression and no $V E G F$ induction by pressure application, compared with 2D conditions. Better access to the surrounding medium due to an overall increase in surface area of the solid scaffold may have led to the better oxygen supply of the cells and, thus, to less VEGF expression. It was only from a force of $6 \mathrm{~g} / \mathrm{cm}^{2}$ that more $V E G F$ was expressed under pressure than in 2D. Since we suspect that the increased VEGF expression in hydrogels and spheroids is mainly generated by a lack of oxygen, solid 3D scaffolds might be better in this area to study the pure mechanical effect of OTM.

The gene collagen-type-1-alpha-2 (COL1A2) encodes the alpha-2 chain of collagen type I, the predominant collagen in the extracellular matrix of the periodontal ligament [39]. Upregulation of this gene, therefore, indicates higher collagen synthesis by PDLFs. The results show an overall clear drop in COL1A2 expression during three-dimensional cultivation of PDLFs with spheroids embedded in hydrogel showing the lowest gene quantity. This may be due to matrix-dependent changes in cell morphology and a lower stimulus of an already existing 3D scaffold to produce ECM proteins [40,41]. In addition, it is described that the matrix-remodelling capacity of fibroblasts depends on the mechanical properties of the environment [29]. Thus, the altered mechanical properties of a three-dimensional matrix, compared with a 2D cell culture, may have reduced the remodelling activity of PDLFs. Flat-attached PDLFs on a rigid polystyrene base may undergo higher mechanical stress than in their spindle-shaped state in a 3D environment, even without additional application of pressure. This assumption is supported by the observation that PDLFs need higher mechanical strain in a 3D culture, compared with 2D conditions, to increase the expression of COL1A2. Berendsen et al., who exposed PDLFs in a collagen gel to tension, have made similar observations and only reported upregulated COL1A1 expression levels under higher mechanical strain, while low forces showed no effect [42].

The secretion of proinflammatory cytokines is an integral step in the signalling cascade from external orthodontic force application to matrix remodelling, bone resorption, and finally tooth movement [8,9]. The investigated proinflammatory genes IL6 and prostaglandinendoperoxide synthase 2 (PTGS2) show different levels of expression highly dependent on the extracellular environment. It is remarkable that especially under spheroid formation the base level of inflammatory expression by PDLFs is massively increased, compared with PDLFs in 2D culture. A study by Vaheri et al. describes a new pathway of cell activation by PDLFs cultured in spheroids, leading to a massive proinflammatory, proteolytic, and growth factor response simultaneously undergoing a process characterised as programmed necrosis-like death [43]. This phenomenon was only observed with healthy adherent cells, while adherent cells derived from solid tumours form actively growing spheroids $[43,44]$. In contrast, PDLFs cultivated on solid 3D scaffolds showed a reduced base level of proinflammatory genes and a higher induction of PTGS2 by pressure application, compared with the 2D culture. This lower level of proinflammatory gene expression by PDLFs on solid 3D scaffolds is in line with the findings by Htwe et al., who observed a reduced level of NF- $k B$ activation by lung fibroblasts in a porous scaffold, compared with $2 \mathrm{D}$, probably due to a lower TNF receptor expression pattern [45]. Subsequently, the reduced levels in NF- $\mathrm{B}$ expression can downregulate the expression of proinflammatory genes [46]. In our opinion, the higher expression of proinflammatory cytokines without cell stimulation in hydrogels and spheroids does not approximate the in vivo situation, as a healthy periodontium without mechanical stimulation should have a low expression level of proinflammatory markers. From this point of view, three-dimensional cultivation on solid scaffolds seems to be more suitable for the investigation of orthodontic pressure application.

Receptor activator of NF- $\mathrm{kB}$ ligand $(R A N K L)$ and its decoy receptor osteoprotegerin $(O P G)$ are the regulating cytokines in initiating bone resorption or apposition and, thus, 
have integral roles in the cellular processes of orthodontic tooth movement and toothroot resorption $[47,48]$. RANKL triggers the differentiation of osteoclast precursor cells to osteoclasts and the activation of premature osteoclasts. As already shown in many experiments with PDLFs $[49,50]$, in 2D on standard cell culture dishes a downregulation of $O P G$ and simultaneous upregulation of RANKL under mechanical strain has been observed. Interestingly, in all investigated three-dimensional cell cultures, a downregulation of $O P G$ under pressure application was no longer significant, while $R A N K L$ upregulation was seen in hydrogels, spheroids, spheroids in hydrogels, as well as on NF and POR scaffolds. With higher compressive forces and longer incubation time, OPG even seemed to be upregulated by tendency, while the magnitude of RANKL induction was reduced. A similar effect has been observed with osteoblasts sharing ultrastructural similarities with PDLFs [51], which expressed higher levels of OPG in correlation to higher magnitudes of compression, while RANKL mRNA expression reached its maximum at $2 \mathrm{~g} / \mathrm{cm}^{2}$ and declined with higher mechanical forces [52]. This phenomenon was discussed by Shen et al. as a dual role of compressive stress with protective inhibition of osteoclastogenesis above a certain threshold [52]. This hypothesis is also supported by the observation that increasing the force magnitude does not accelerate tooth movement [53]. Additionally, the established 2D culture systems offered an easy-to-understand mechanical force induction, since one can assume that all adherent PDLFs flat-attached to the polystyrene base experience nearly the same force vector. In a complex 3D environment, such as the periodontal ligament in vivo, the initially applied force vector is probably divided and diverted into several smaller force vectors pointing into different directions. In some areas of the 3D matrix, this may even induce zones of tension favouring OPG over RANKL induction to initiate bone apposition [54,55]. This may be another explanation for the differences in $R A N K L$ and $O P G$ expression in different 3D cultures and requires further research. Overall, with the exception of the NF/MF and MF scaffolds, all 3D cell culture models showed regulation of the RANKL/OPG system under pressure application, as it would be expected with respect to osteoclastogenesis in pressure zones of the periodontal ligament in vivo.

These results show that the choice of 3D culture significantly influences cell behaviour and should, therefore, be considered carefully. It must be taken into account that this study is limited in the number of genes investigated, which means that processes that we do not know about yet might be altered by one or the other form of 3D cell culture. It must also be stated that, as of today, there is a wide variety of three-dimensional matrices described in the literature, which we were not able to examine in total within the scope of this study, although we sought to investigate a broad spectrum of different forms of $3 \mathrm{D}$ cell culture. In addition, hydrogels and scaffold-based matrices, in particular, offer the possibility for modifications such as the adjustment of physical properties and coating with proteins, which provide almost infinite possibilities for optimisation and alteration of cell culture conditions [31]. This must be part of future investigations. Finally, it must also be mentioned that 3D cell cultures may be a good approximation to in vivo experiments, but animal experiments remain essential in further investigations of hypotheses based on in vitro experiments.

\section{Materials and Methods}

\subsection{Isolation and Cultivation of PDLFS}

Primary human PDLFs were isolated from the periodontal connective tissue of extracted human teeth of healthy donors that were free of decay and periodontal disease and were extracted for medical reasons. Tissue samples were cultivated in six-well cell culture plates (353046, Corning $\mathrm{GmbH}$, Kaiserslautern, Germany) $\left(37^{\circ} \mathrm{C}, 5 \% \mathrm{CO}_{2}, 100 \% \mathrm{H}_{2} \mathrm{O}\right)$ in complete media (DMEM High Glucose, D5671, Merck KGaA, Darmstadt, Germany) with 10\% FBS (P30-3302, PAN-Biotech GmbH, Aidenbach, Germany); 1\% antibiotic/antimycotic (A5955, Merck KGaA, Darmstadt, Germany); 1\% L-glutamine (G7513, Merck KGaA, Darmstadt, Germany) and $100 \mu \mathrm{M}$ ascorbic acid (A8960, Merck KGaA, Darmstadt, Germany) until proliferative outgrowth of adherently growing fibroblasts was observed. Cells were 
characterised by human PDLF-specific marker genes and a spindle-shaped morphology, as reported previously $[49,56]$. For the experiments, human PDLFs from the third to fifth passage were pooled from six patients (male: 3; female: 3; age: 17-27 years).

\subsection{Cell Culture Experiments with Hydrogel and Spheroids}

In the first cell culture experiment, we investigated the effect of compressive strain on the expression profiles of PDLFs cultivated in 2D on standard cell culture dishes or in 3D as monolayers in Mebiol ${ }^{\circledR}$ gel (MBG-PMW20-5001, Cosmo Bio, Carlsbad, CA, USA; Figure 5a), as spheroid formation on standard cell culture dishes, or as spheroids in Mebiol ${ }^{\circledR}$ gel (Figure 5b).
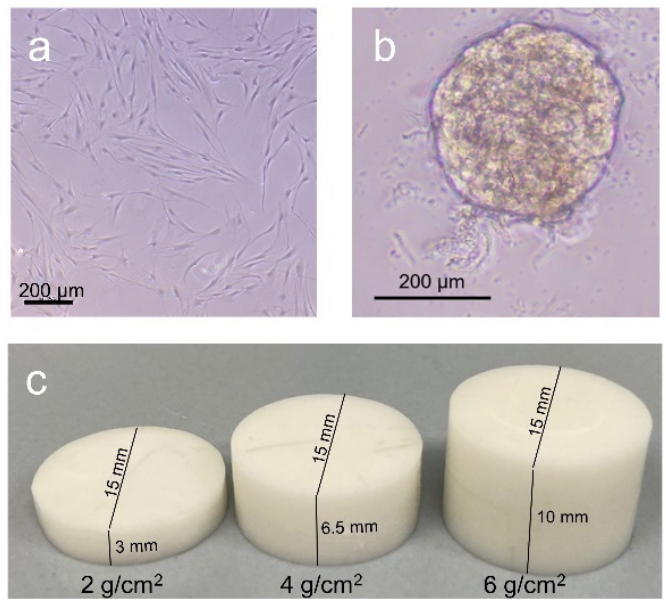

Figure 5. PDLFs either cultured as a conventional monolayer in $\mathrm{Mebiol}^{\circledR}$ gel (a) or as spheroids in $\mathrm{Mebiol}^{\circledR}$ gel (b) were compressed with $\mathrm{ZnO}_{2}$ plates of different heights (c) to achieve different compression magnitudes.

For spheroid formation, three sterile 96-well cell culture plates (353072, Corning $\mathrm{GmbH}$, Kaiserslautern, Germany) were used per experiment. In each well, $75 \mu \mathrm{L} 1 \%$ agarose (6351.5, Carl Roth GmbH, Karlsruhe, Germany) in PBS (14190-094, Thermo Fisher Scientific, Langenselbold, Germany) was added to prevent the PDLFs from growing on the bottom of the cell culture plate and to induce spherical agglomeration of the PDLFs (Figure 5b). After the agarose had been cured, 100,000 PDLFs per $\mathrm{mL}$ were seeded onto the three sterile 96-well cell culture plates and incubated for $72 \mathrm{~h}$ under cell culture conditions. Mebiol ${ }^{\circledR}$ gel is a thermoreversible hydrogel that gels at $37^{\circ} \mathrm{C}$ and changes to a liquid state at $4{ }^{\circ} \mathrm{C}$. The Mebiol ${ }^{\circledR}$ gel used (MBG-PMW20-5001, Cosmo Bio, Carlsbad, CA, USA) is available in freezedried form on the back of a T75 bottle (83.3911.002, Sarstedt, Nümbrecht, Germany). At least $72 \mathrm{~h}$ before seeding of the PDLFs or spheroids, $50 \mathrm{~mL}$ of DMEM High Glucose (D5671, Merck KGaA, Darmstadt, Germany) supplemented with 10\% FBS (P30-3302, PAN-Biotech GmbH, Aidenbach, Germany), 1\% antibiotic/antimycotic (A5955, Merck KGaA, Darmstadt, Germany), 1\% L-glutamine (G7513, Merck KGaA, Darmstadt, Germany), and $100 \mu \mathrm{M}$ ascorbic acid (A8960, Merck KGaA, Darmstadt, Germany) were added to the lyophilised Mebiol ${ }^{\circledR}$ gel and initially stored at $4{ }^{\circ} \mathrm{C}$ for $3 \mathrm{~h}$. The T75 bottle was then gently swirled and stored at $4{ }^{\circ} \mathrm{C}$ until use. A conventional 24-well cell culture plate (662-160, Greiner Bio-One $\mathrm{GmbH}$, Frickenhausen, Germany) was used to implement the following experimental setup. Prior to seeding the PDLF single cells, PDLFs were trypsinised. For PDLFs in 2D culture, 50,000 cells per mL were dissolved in full medium, while 100,000 PDLFs were seeded in $200 \mu \mathrm{L}$ Mebiol ${ }^{\circledR}$ gel. For this purpose, the cell suspension was centrifuged at $800 \mathrm{rpm}$ for $10 \mathrm{~min}$. The cell pellet was taken up in Mebiol ${ }^{\circledR}$ gel on ice to maintain the liquid state of the hydrogel. The spheroids that had been cultivated on the three 96-well cell culture plates were removed with a $1 \mathrm{~mL}$ pipette, transferred to two prepared $15 \mathrm{~mL}$ Falcon tubes (62.554.502, Sarstedt, Nümbrecht, Germany ), each containing 144 spheroids, and 
centrifuged at $1200 \mathrm{rpm}$ for $15 \mathrm{~min}$. One of the resulting cell pellets was dissolved in $3.1 \mathrm{~mL}$ of complete medium, while the other was taken up in $1.3 \mathrm{~mL}$ of ice-cold Mebiol ${ }^{\circledR}$ gel. Prior to culturing the spheroids, $200 \mu \mathrm{L}$ of $1 \%$ agarose in PBS were placed per well to prevent adherence of the PDLFs by reattachment to the plastic surface of the wells. After hardening of the agarose, 24 of the spheroids dissolved in the full medium could be placed in each well. For another group of experiments, 24 spheroids were seeded in $200 \mu \mathrm{L}$ of Mebiol ${ }^{\circledR}$ gel per well under refrigerated conditions. The cell culture plate was then removed from the ice to allow the Mebiol ${ }^{\circledR}$ gel to solidify. After the complete hardening of the hydrogel, $300 \mu \mathrm{L}$ of the full medium was added and finally incubated under cell culture conditions. After $24 \mathrm{~h}$ of preincubation, the corresponding pressure groups were loaded with sterile zirconium oxide $\left(\mathrm{ZnO}_{2}\right)$ plates with a force of $2 \mathrm{~g} / \mathrm{cm}^{2}$ (Cercon Base, 763,180, Dentsply Sirona $\mathrm{GmbH}$, Bensheim, Germany; Figure 5c) for $48 \mathrm{~h}$. These ceramic plates were milled in-house from zirconia blanks using the CAD/CAM process to the required dimensions and sterilised using hot air sterilisation at $200{ }^{\circ} \mathrm{C}$ for $2 \mathrm{~h}$. After the incubation period, RNA was isolated and analysed with RT-qPCR. The supernatant was used for LDH assay (Supplemental Materials).

\subsection{Cell Culture Experiments with 3D Scaffolds}

To investigate the impact of different 3D scaffolds, we used the InoMATRIX morphology selection plate (811000-24, Biozym Scientific GmbH, Hessisch Oldendorf, Germany) in a 24-well plate format containing three-dimensional scaffold discs made of poly- $\varepsilon$-caprolactone (PCL) with a standard thickness of $200 \mu \mathrm{m}$ per well. The fibre morphology of these scaffold discs varied per row of the 24-well plate. Thus, in the first row, there were six scaffolds of nanofibres (NFs) with a fibre diameter of $200 \mathrm{~nm}$, while in the second row, there were six scaffolds of a mixture material of nanofibres and microfibres (NFs/MFs). Scaffolds solely based on microfibres (MFs) were placed in the third row with a fibre diameter of $5 \mu \mathrm{m}$. In the fourth row, there were scaffolds of porous fibres with a nanostructured surface (POR). For each series of experiments, a selection plate was used and the first row of a conventional polystyrene 24-well plate was used as a control. PDLFs were seeded in DMEM High Glucose (D5671, Merck KGaA, Darmstadt, Germany) supplemented with 10\% FBS (P30-3302, PANBiotech $\mathrm{GmbH}$, Aidenbach, Germany); 1\% antibiotic/antimycotic (A5955, Merck KGaA, Darmstadt, Germany); 1\% L-glutamine (G7513, Merck KGaA, Darmstadt, Germany), and $100 \mu \mathrm{M}$ ascorbic acid (A8960, Merck KGaA, Darmstadt, Germany) and preincubated for $24 \mathrm{~h}$ under cell culture conditions. $\mathrm{ZnO}_{2}$ plates were then applied to half of the wells with a compressive force of $2 \mathrm{~g} / \mathrm{cm}^{2}$ (Figure $5 \mathrm{c}$ ) and for a period of $48 \mathrm{~h}$. The other half remained untreated. Afterwards, the discs were removed, and RNA was isolated and analysed with RT-qPCR. The supernatant was used for the LDH assay (Supplemental Materials).

\subsection{Cell Culture Experiments in POR Scaffolds with Different Magnitudes of Compression}

To assess the optimal compression force in the POR scaffold, PDLFs were seeded in DMEM High Glucose (D5671, Merck KGaA, Darmstadt, Germany) supplemented with 10\% FBS (P303302, PAN-Biotech GmbH, Aidenbach, Germany); 1\% antibiotic/antimycotic (A5955, Merck KGaA, Darmstadt, Germany); 1\% L-glutamine (G7513, Merck KGaA, Darmstadt, Germany), and $100 \mu \mathrm{M}$ ascorbic acid (A8960, Merck KGaA, Darmstadt, Germany) either on conventional 24-well cell culture plates (662-160, Greiner Bio-One GmbH, Frickenhausen, Germany) or on 24-well INOMatrix plates (Porous POR PCL Morphology Single Type Plate, 811004-24, Biozym Scientific $\mathrm{GmbH}$, Hessisch Oldendorf, Germany) and loaded with $\mathrm{ZnO}_{2}$ plates of different weights $\left(2 \mathrm{~g} / \mathrm{cm}^{2}, 4 \mathrm{~g} / \mathrm{cm}^{2}, 6 \mathrm{~g} / \mathrm{cm}^{2}\right)$ (Figure $5 \mathrm{c}$ ), for $48 \mathrm{~h}$ after $24 \mathrm{~h}$ of preincubation, under cell culture conditions. After the compression period, RNA was isolated and analysed with RT-qPCR. The supernatant was used for the LDH assay (Supplemental Materials).

\subsection{Cell Culture Experiments in POR Scaffolds with Different Periods of Compression}

To assess the optimal compression time in the POR scaffold, PDLFs were cultured for $4,24,48$, and $72 \mathrm{~h}$ either on conventional 24-well cell culture plates (662-160, Greiner 
Bio-One GmbH, Frickenhausen, Germany) or on 24-well INO matrix plates (Porous POR PCL Morphology Single Type Plate, 811004-24, Biozym Scientific GmbH, Hessisch Oldendorf, Germany) in DMEM High Glucose (D5671, Merck KGaA, Darmstadt, Germany) supplemented with 10\% FBS (P30-3302, PAN-Biotech GmbH, Aidenbach, Germany); 1\% antibiotic/antimycotic (A5955, Merck KGaA, Darmstadt, Germany); 1\% L-glutamine (G7513, Merck KGaA, Darmstadt, Germany), and $100 \mu \mathrm{M}$ ascorbic acid (A8960, Merck KGaA, Darmstadt, Germany). After $24 \mathrm{~h}$ of preincubation, the cells were either left untreated or compressed with $\mathrm{ZnO}_{2}$ plates $\left(2 \mathrm{~g} / \mathrm{cm}^{2}\right)$. Depending on the periods to be investigated, the plates were left on the cells for $4,24,48$, or $72 \mathrm{~h}$. After the corresponding incubation time, RNA was isolated and analysed with RT-qPCR. The supernatant was used for the LDH assay (Supplemental Materials).

\subsection{RNA Isolation}

The Trizol method was used to isolate RNA. After incubation time, the supernatant was removed from the cells. To extract the RNA, $250 \mu \mathrm{L}$ of phenol-containing RNA-Solv reagent (R6830-01, VWR International $\mathrm{GmbH}$, Darmstadt, Germany) was pipetted per well. After a short reaction time, the entire volume was transferred to a previously prepared tube (Safe Seal, 72.706, Sarstedt, Nümbrecht, Germany) and $100 \mu \mathrm{L}$ of chloroform (4432.1, Carl Roth $\mathrm{GmbH}$, Karlsruhe, Germany) was added to each. Each sample was vortexed for $30 \mathrm{~s}$, incubated on ice for $15 \mathrm{~min}$, and centrifuged for another $15 \mathrm{~min}$ at $4{ }^{\circ} \mathrm{C}$ and $13,000 \mathrm{rpm}$ (HERAEUS Fresko 17, Thermo Fisher Scientific Technologies, Langenselbold, Germany). The aqueous supernatant was transferred to a tube with $500 \mu \mathrm{L}$ isopropanol (20.842.330, VWR International $\mathrm{GmbH}$, Darmstadt, Germany). The samples were incubated at $-80^{\circ} \mathrm{C}$ overnight and then centrifuged for $30 \mathrm{~min}$ at $4{ }^{\circ} \mathrm{C}$ and $13,000 \mathrm{rpm}$, and the supernatant was removed. The RNA was further purified by adding $500 \mu \mathrm{L}$ of $80 \%$ ethanol, and samples were centrifuged at $13,000 \mathrm{rpm}$ and $4{ }^{\circ} \mathrm{C}$ for a further $10 \mathrm{~min}$. After repeating the process, the RNA pellet was dried for at least $30 \mathrm{~min}$. To determine the RNA concentration, the pellet of each sample was resuspended in $10 \mu \mathrm{L}$ nuclease-free $\mathrm{H}_{2} \mathrm{O}_{\mathrm{dd}}$ (T143.5, Carl Roth $\mathrm{GmbH}$, Karlsruhe, Germany). Subsequently, $1.5 \mu \mathrm{L}$ of each sample was measured in a photometer (NanoPhotometer N60, Implen GmbH, Munich, Germany).

\section{7. cDNA Synthesis}

Information about the expression profiles of the PDLFs to be investigated was obtained from the purified RNA. For this purpose, cDNA was synthesised from the isolated RNA using reverse transcriptase. In order to use the same RNA concentration for the reaction, the isolated RNA was diluted with nuclease-free $\mathrm{H}_{2} \mathrm{O}_{\mathrm{dd}}$ (T143.5, Carl Roth $\mathrm{GmbH}$, Karlsruhe, Germany) according to the measured concentration. Depending on the chosen approach, 4 or $8 \mu \mathrm{L}$ RNA and 1 or $2 \mu \mathrm{L}$ LunaScript RT SuperMix (E3010L, New England Biolabs $\mathrm{GmbH}$, Frankfurt am Main, Germany) were added to the nuclease-free $\mathrm{H}_{2} \mathrm{O}_{\mathrm{dd}}$. The samples were placed in a thermocycler (Thermocycler Tone 96G-Biometra, Analytik Jena GmbH, Jena, Germany) and incubated for $2 \mathrm{~min}$ at $25^{\circ} \mathrm{C}$ and then $10 \mathrm{~min}$ at $55^{\circ} \mathrm{C}$. The reverse transcriptase was inactivated by heating to $95{ }^{\circ} \mathrm{C}$ for $1 \mathrm{~min}$. The cDNA was then mixed with $45 \mu \mathrm{L}$ nuclease-free $\mathrm{H}_{2} \mathrm{O}_{\mathrm{dd}}$ (T143.5, Carl Roth $\mathrm{GmbH}$, Karlsruhe, Germany) and stored at $-20{ }^{\circ} \mathrm{C}$ until use.

\subsection{Quantitative Real-Time PCR (RT-qPCR)}

A primer mix consisting of $0.25 \mu \mathrm{L}$ forward, $0.25 \mu \mathrm{L}$ reverse primer (Table 1), $3 \mu \mathrm{L}$ nuclease-free $\mathrm{H}_{2} \mathrm{O}_{\mathrm{dd}}$ (T143.5, Carl Roth $\mathrm{GmbH}$, Karlsruhe, Germany), and $5 \mu \mathrm{L}$ Luna Universal qPCR Master Mix (M3003E, New England Biolabs GmbH, Frankfurt am Main, Germany) per sample was prepared for RT-qPCR. RT-qPCR was performed in duplicate for each sample. For this procedure, $1.5 \mu \mathrm{L}$ of $\mathrm{cDNA}$ was pipetted onto a 96-well plate (712282, Biozym Scientific GmbH, Hessisch Oldendorf, Germany) and centrifuged. After the addition of $8.5 \mu \mathrm{L}$ primer mix and repeated centrifugation, the plate was covered with an adhesive optical film (712350, Biozym Scientific $\mathrm{GmbH}$, Hessisch Oldendorf, Germany). 
For evaluation of the expression profile, the plate was placed in the Realplex2 (Eppendorf $\mathrm{Ag}$, Hamburg, Germany), and the appropriate programme $\left(95^{\circ} \mathrm{C}\right.$ for 2 min and 45 cycles with $10 \mathrm{~s} 95^{\circ} \mathrm{C}, 20 \mathrm{~s} 60^{\circ} \mathrm{C}, 8 \mathrm{~s} 72^{\circ} \mathrm{C}$ ) was started. To determine the relative gene expression, the formula $2^{-\Delta \mathrm{Cq}}$ (Livak et al., 2001), with $\Delta \mathrm{Cq}=\mathrm{Cq}$ (target gene) $-\mathrm{Cq}$ (geometric mean $P P I B / R P L 22)$ was used. Reference genes have been validated before [56]. For evaluation of the spheroid experiment, only reference gene RPL22 was used, as PPIB showed reduced expression. All primers (Table 1) were designed according to the MIQE quality guidelines (Bustin et al., 2009).

Table 1. Primer sequences for reference genes and target genes.

\begin{tabular}{|c|c|c|c|}
\hline $\begin{array}{c}\text { Gene } \\
\text { Symbol }\end{array}$ & Gene Name & $5^{\prime}$-Forward Primer- $3^{\prime}$ & $5^{\prime}$-Reverse Primer-3' \\
\hline COL1A2 & Collagen-type-I-alpha-2 & AGAAACACGTCTGGCTAGGAG & GCATGAAGGCAAGTTGGGTAG \\
\hline IL6 & Interleukin-6 & TGGCAGAAAACAACCTGAACC & CСТCAAACTCCAAAAGACCAGTG \\
\hline$O P G$ & Osteoprotegerin & TGTCTTTGGTCTCCTGCTAACTC & ACGCTCCAGGACTTATACCG \\
\hline$P P I B$ & Peptidylprolyl isomerase A & TTCCATCGTGTAATCAAGGACTTC & GCTCACCGTAGATGCTCTTTC \\
\hline PTGS2 & $\begin{array}{l}\text { Prostaglandin endoperoxide } \\
\text { synthase } 2\end{array}$ & GAGCAGGCAGATGAAATACCAGTC & TGTCACCATAGAGTGCTTCCAAC \\
\hline RANKL & $\begin{array}{l}\text { Receptor activator of NFk-B } \\
\text { ligand }\end{array}$ & ATACCCTGATGAAAGGAGGA & GGGGCTCAATCTATATCTCG \\
\hline RPL22 & Ribosomal protein L22 & TGATTGCACCCACCCTGTAG & GGTTCCCAGCTTTTCCGTTC \\
\hline$V E G F$ & $\begin{array}{l}\text { Vascular endothelial growth } \\
\text { factor }\end{array}$ & TGCAGACCAAAGAAAGATAGAGC & ACGCTCCAGGACTTATACCG \\
\hline
\end{tabular}

\subsection{Statistical Methods}

All experiments were performed at least two times with three biological replicates each. RT-qPCR and LDH assays were performed as technical duplicates for each biological sample. $n$ stated in the figure legends represents all biological replicates used for statistical analysis. Prior to statistical analysis, all absolute data values were divided by the arithmetic mean of the control group, to normalise data values to these controls. Quantitative data were presented as mean and standard deviation. We first determined the normal distribution of data using the Shapiro-Wilk test. For data with normal distribution, we performed ANOVA with Holm-Sidak's multiple comparison tests, and for data that were not normally distributed, we performed Welch-corrected ANOVA with Games-Howell multiple comparison tests. Statistical analysis was performed with GraphPad Prism Version 9.1 (GraphPad Software, San Diego, CA, USA). Differences were deemed statistically significant at $p<0.05$.

\section{Conclusions}

The expression of angiogenetic, proinflammatory, and osteogenic cytokines is vastly dependent on the environment in which the PDLFs are cultivated. Not only do cells, particularly extracellular-matrix-forming cells, behave very differently and probably more similar to in vivo conditions in a three-dimensional environment, compared with a standard 2D culture, as already stated in the literature [27,57,58], but variations among different types of 3D culture are also apparent. As Duval et al. have already stated, the gene expression of each 3D culture is specific in adaptation to its microenvironment [20]. Our initial results show higher levels of VEGF expression in hydrogels and spheroids, indicating reduced oxygen supply in these cultures. Furthermore, a higher expression level of proinflammatory cytokines in these three-dimensional cultures, even under control conditions without pressure application, seems to be less accurate in replicating the in vivo situation. Concerning osteoclastogenesis, RANKL was upregulated in all 3D cultures but not on NF/MF and MF scaffolds. Thus, as seen from current data, we recommend the usage of solid scaffolds in future research of pressure application on PDLFs, in particular the usage of scaffolds with a nanofibre (NF) or porous (POR) structure. On these scaffolds, we suggest a pressure 
application of $2 \mathrm{~g} / \mathrm{cm}^{2}$ for $48 \mathrm{~h}$ as in $2 \mathrm{D}$ culture on standard cell culture dishes, as other force magnitudes and incubation times led to lower RANKL but higher VEGF expression.

Supplementary Materials: The following supporting information can be downloaded at: https:// www.mdpi.com/article/10.3390/ijms23042029/s1.

Author Contributions: Conceptualisation, A.S., C.K. and N.U.; methodology, A.S., R.S. and J.O.; validation, J.J., C.K. and N.U.; formal analysis, A.S.; investigation, A.S., R.S. and J.O.; resources, P.P. and G.S.; data curation, R.S. and J.O.; writing — original draft preparation, A.S. and N.U.; writing-review and editing, A.S., J.J., C.K. and N.U.; visualisation, A.S.; supervision, P.P.; project administration, A.S.; funding acquisition, N.U. All authors have read and agreed to the published version of the manuscript.

Funding: This study was funded by the Else Kröner-Fresenius-Stiftung (Grant ID: 3752913).

Institutional Review Board Statement: All teeth used for isolation of human PDLFs were extracted for medical reasons only. Approval for the collection and usage of PDLFs was obtained from the ethics committee of the University of Regensburg, Germany (Approval Number 12-170-0150).

Informed Consent Statement: Not applicable.

Data Availability Statement: The data underlying this article will be shared at reasonable request to the corresponding author.

Acknowledgments: The authors thank Kathrin Bauer and Eva Zaglauer for their technical support.

Conflicts of Interest: The authors report no financial or other conflict of interest relevant to this article, which is the intellectual property of the authors. Furthermore, no part of this article has been published before or considered for publication elsewhere.

\section{References}

1. $\quad$ Proffit, W.R.; Fields, H.W.; Larson, B.E.; Sarver, D.M. Contemporary Orthodontics; Elsevier: Philadelphia, PA, USA, 2019.

2. Sharma, S.; Narkhede, S.; Sonawane, S.; Gangurde, P. Evaluation of Patient's Personal Reasons and Experience with Orthodontic Treatment. J. Int. Oral Health 2013, 5, 78-81. [PubMed]

3. Grimm, S.; Frazão, P.; Antunes, J.L.F.; Castellanos, R.A.; Narvai, P.C. Dental injury among Brazilian schoolchildren in the state of São Paulo. Dent. Traumatol. 2004, 20, 134-138. [CrossRef] [PubMed]

4. Gaikwad, S.S.; Gheware, A.; Kamatagi, L.; Pasumarthy, S.; Pawar, V.; Fatangare, M. Dental caries and its relationship to malocclusion in permanent dentition among 12-15 year old school going children. J. Int. Oral Health 2014, 6, 27-30. [PubMed]

5. Geiger, A.M. Malocclusion as an etiologic factor in periodontal disease: A retrospective essay. Am. J. Orthod. Dentofac. Orthop. 2001, 120, 112-115. [CrossRef] [PubMed]

6. Zanella, S.M.; Pereira, S.S.; Barbisan, J.N.; Vieira, L.; Saba-Chujfi, E.; Haas, A.N.; Rösing, C.K. Periodontal disease, tooth loss and coronary heart disease assessed by coronary angiography: A cross-sectional observational study. J. Periodontal Res. 2016, 51, 221-227. [CrossRef] [PubMed]

7. Sandy, J.R.; Farndale, R.W.; Meikle, M.C. Recent advances in understanding mechanically induced bone remodeling and their relevance to orthodontic theory and practice. Am. J. Orthod. Dentofac. Orthop. 1993, 103, 212-222. [CrossRef]

8. Meikle, M.C. The tissue, cellular, and molecular regulation of orthodontic tooth movement. 100 years after Carl Sandstedt. Eur. J. Orthod. 2006, 28, 221-240. [CrossRef]

9. Kanzaki, H.; Chiba, M.; Shimizu, Y.; Mitani, H. Periodontal ligament cells under mechanical stress induce osteoclastogenesis by receptor activator of nuclear factor kappaB ligand up-regulation via prostaglandin E2 synthesis. J. Bone Miner. Res. 2002, 17, 210-220. [CrossRef]

10. Beertsen, W.; McCulloch, C.A.; Sodek, J. The periodontal ligament: A unique, multifunctional connective tissue. Periodontol. 2000 1997, 13, 20-40. [CrossRef]

11. Hassell, T.M. Tissues and cells of the periodontium. Periodontol. 2000 1993, 3, 9-38. [CrossRef]

12. McCulloch, C.A.; Bordin, S. Role of fibroblast subpopulations in periodontal physiology and pathology. J. Periodontal Res. 1991, 26 Pt 1, 144-154. [CrossRef]

13. Lekic, P.; McCulloch, C. Periodontal ligament cell populations: The central role of fibroblasts in creating a unique tissue. Anat. Rec. 1996, 245, 327-341. [CrossRef]

14. Krishnan, V.; Davidovitch, Z. Cellular, molecular, and tissue-level reactions to orthodontic force. Am. J. Orthod. Dentofac. Orthop. 2006, 129, 469.E1-469.E32. [CrossRef] [PubMed]

15. Di Domenico, M.; D’apuzzo, F.; Feola, A.; Cito, L.; Monsurrò, A.; Pierantoni, G.M.; Berrino, L.; de Rosa, A.; Polimeni, A.; Perillo, L. Cytokines and VEGF induction in orthodontic movement in animal models. J. Biomed. Biotechnol. 2012, 2012, 201689. [CrossRef] [PubMed] 
16. Graber, L.W.; Vanarsdall, R.L.; Vig, K.W.L.; Huang, G.J. Orthodontics. Current Principles and Techniques, 6th ed.; Elsevier: St. Louis, MI, USA, 2017.

17. Baumrind, S.; Buck, D.L. Rate changes in cell replication and protein synthesis in the periodontal ligament incident to tooth movement. Am. J. Orthod. 1970, 57, 109-131. [CrossRef]

18. Baker, B.M.; Chen, C.S. Deconstructing the third dimension: How 3D culture microenvironments alter cellular cues. J. Cell Sci. 2012, 125 Pt 13, 3015-3024. [CrossRef]

19. Thippabhotla, S.; Zhong, C.; He, M. 3D cell culture stimulates the secretion of in vivo like extracellular vesicles. Sci. Rep. 2019, 9, 13012. [CrossRef]

20. Duval, K.; Grover, H.; Han, L.-H.; Mou, Y.; Pegoraro, A.F.; Fredberg, J.; Chen, Z. Modeling Physiological Events in 2D vs. 3D Cell Culture. Physiology (Bethesda) 2017, 32, 266-277. [CrossRef]

21. Loessner, D.; Stok, K.S.; Lutolf, M.P.; Hutmacher, D.W.; Clements, J.A.; Rizzi, S.C. Bioengineered 3D platform to explore cell-ECM interactions and drug resistance of epithelial ovarian cancer cells. Biomaterials 2010, 31, 8494-8506. [CrossRef]

22. Zorlutuna, P.; Annabi, N.; Camci-Unal, G.; Nikkhah, M.; Cha, J.M.; Nichol, J.W.; Manbachi, A.; Bae, H.; Chen, S.; Khademhosseini, A Microfabricated biomaterials for engineering 3D tissues. Adv. Mater. 2012, 24, 1782-1804. [CrossRef]

23. Brezulier, D.; Pellen-Mussi, P.; Tricot-Doleux, S.; Novella, A.; Sorel, O.; Jeanne, S. Development of a 3D human osteoblast cell culture model for studying mechanobiology in orthodontics. Eur. J. Orthod. 2020, 42, 387-395. [CrossRef] [PubMed]

24. Rodrigues, J.; Heinrich, M.A.; Teixeira, L.M.; Prakash, J. 3D In Vitro Model (R)evolution: Unveiling Tumor-Stroma Interactions. Trends Cancer 2021, 7, 249-264. [CrossRef] [PubMed]

25. Mabry, K.M.; Payne, S.Z.; Anseth, K.S. Microarray analyses to quantify advantages of 2D and 3D hydrogel culture systems in maintaining the native valvular interstitial cell phenotype. Biomaterials 2016, 74, 31-41. [CrossRef]

26. Melissaridou, S.; Wiechec, E.; Magan, M.; Jain, M.V.; Chung, M.K.; Farnebo, L.; Roberg, K. The effect of 2D and 3D cell cultures on treatment response, EMT profile and stem cell features in head and neck cancer. Cancer Cell Int. 2019, 19, 16. [CrossRef] [PubMed]

27. Bott, K.; Upton, Z.; Schrobback, K.; Ehrbar, M.; Hubbell, J.A.; Lutolf, M.P.; Rizzi, S.C. The effect of matrix characteristics on fibroblast proliferation in 3D gels. Biomaterials 2010, 31, 8454-8464. [CrossRef]

28. Jensen, C.; Teng, Y. Is It Time to Start Transitioning from 2D to 3D Cell Culture? Front. Mol. Biosci. 2020, 7, 33. [CrossRef] [PubMed]

29. Rhee, S. Fibroblasts in three dimensional matrices: Cell migration and matrix remodeling. Exp. Mol. Med. 2009, 41, 858. [CrossRef] [PubMed]

30. Li, M.; Zhang, C.; Yang, Y. Effects of mechanical forces on osteogenesis and osteoclastogenesis in human periodontal ligament fibroblasts: A systematic review of in vitro studies. Bone Joint Res. 2019, 8, 19-31. [CrossRef]

31. Nikolova, M.P.; Chavali, M.S. Recent advances in biomaterials for 3D scaffolds: A review. Bioact. Mater. 2019, 4, 271-292. [CrossRef]

32. Knight, E.; Przyborski, S. Advances in 3D cell culture technologies enabling tissue-like structures to be created in vitro. J. Anat. 2015, 227, 746-756. [CrossRef]

33. Laschke, M.W.; Menger, M.D. Life is 3D: Boosting Spheroid Function for Tissue Engineering. Trends Biotechnol. 2017, 35, 133-144. [CrossRef] [PubMed]

34. Lin, Y.-N.; Nasir, A.; Camacho, S.; Berry, D.L.; Schmidt, M.O.; Pearson, G.W.; Riegel, A.T.; Wellstein, A. Monitoring Cancer Cell Invasion and T-Cell Cytotoxicity in 3D Culture. JoVE J. 2020, e61392. [CrossRef] [PubMed]

35. Liu, W.; Shen, S.-M.; Zhao, X.-Y.; Chen, G.-Q. Targeted genes and interacting proteins of hypoxia inducible factor-1. Int. J. Biochem. Mol. Biol. 2012, 3, 165-178.

36. Kuschel, A.; Simon, P.; Tug, S. Functional regulation of HIF-1 $\alpha$ under normoxia-Is there more than post-translational regulation? J. Cell. Physiol. 2012, 227, 514-524. [CrossRef] [PubMed]

37. Li, M.L.; Yi, J.; Yang, Y.; Zhang, X.; Zheng, W.; Li, Y.; Zhao, Z. Compression and hypoxia play independent roles while having combinative effects in the osteoclastogenesis induced by periodontal ligament cells. Angle Orthod. 2016, 86, 66-73. [CrossRef] [PubMed]

38. Miyagawa, A.; Chiba, M.; Hayashi, H.; Igarashi, K. Compressive force induces VEGF production in periodontal tissues. J. Dent. Res. 2009, 88, 752-756. [CrossRef] [PubMed]

39. Kook, S.-H.; Hwang, J.-M.; Park, J.-S.; Kim, E.-M.; Heo, J.-S.; Jeon, Y.-M.; Lee, J.-C. Mechanical force induces type I collagen expression in human periodontal ligament fibroblasts through activation of ERK/JNK and AP-1. J. Cell Biochem. 2009, 106, 1060-1067. [CrossRef]

40. Hakkinen, K.M.; Harunaga, J.S.; Doyle, A.D.; Yamada, K.M. Direct comparisons of the morphology, migration, cell adhesions, and actin cytoskeleton of fibroblasts in four different three-dimensional extracellular matrices. Tissue Eng. Part A 2011, 17, 713-724. [CrossRef]

41. Oortgiesen, D.A.W.; Yu, N.; Bronckers, A.L.J.J.; Yang, F.; Walboomers, X.F.; Jansen, J.A. A three-dimensional cell culture model to study the mechano-biological behavior in periodontal ligament regeneration. Tissue Eng. Part C Methods 2012, 18, 81-89. [CrossRef]

42. Berendsen, A.D.; Smit, T.H.; Walboomers, X.F.; Everts, V.; Jansen, J.A.; Bronckers, A.L.J.J. Three-dimensional loading model for periodontal ligament regeneration in vitro. Tissue Eng. Part C Methods 2009, 15, 561-570. [CrossRef] 
43. Vaheri, A.; Enzerink, A.; Räsänen, K.; Salmenperä, P. Nemosis, a novel way of fibroblast activation, in inflammation and cancer. Exp. Cell. Res. 2009, 315, 1633-1638. [CrossRef] [PubMed]

44. Sutherland, R.M. Cell and environment interactions in tumor microregions: The multicell spheroid model. Science 1988, 240, 177-184. [CrossRef] [PubMed]

45. Htwe, S.S.; Harrington, H.; Knox, A.; Rose, F.; Aylott, J.; Haycock, J.W.; Ghaemmaghami, A.M. Investigating NF-kB signaling in lung fibroblasts in 2D and 3D culture systems. Respir. Res. 2015, 16, 144. [CrossRef] [PubMed]

46. Barnes, P.J.; Karin, M. Nuclear factor-kappaB: A pivotal transcription factor in chronic inflammatory diseases. N. Engl. J. Med. 1997, 336, 1066-1071. [CrossRef] [PubMed]

47. Proff, P.; Römer, P. The molecular mechanism behind bone remodelling: A review. Clin. Oral Investig. 2009, 13, 355-362. [CrossRef]

48. Tyrovola, J.B.; Spyropoulos, M.N.; Makou, M.; Perrea, D. Root resorption and the OPG/RANKL/RANK system: A mini review. J. Oral Sci. 2008, 50, 367-376. [CrossRef]

49. Schröder, A. Expression kinetics of human periodontal ligament fibroblasts in the early phases of orthodontic tooth movement J. Orofac. Orthop. 2018, 79, 337-351. [CrossRef]

50. Ullrich, N.; Schröder, A.; Jantsch, J.; Spanier, G.; Proff, P.; Kirschneck, C. The role of mechanotransduction versus hypoxia during simulated orthodontic compressive strain-an in vitro study of human periodontal ligament fibroblasts. Int. J. Oral Sci. 2019, 11, 33. [CrossRef]

51. Ducy, P.; Schinke, T.; Karsenty, G. The osteoblast: A sophisticated fibroblast under central surveillance. Science 2000, 289, 1501-1504. [CrossRef]

52. Shen, X.-Q.; Geng, Y.-M.; Liu, P.; Huang, X.-Y.; Li, S.-Y.; Liu, C.-D.; Zhou, Z.; Xu, P.-P. Magnitude-dependent response of osteoblasts regulated by compressive stress. Sci. Rep. 2017, 7, 44925. [CrossRef]

53. Ren, Y.; Maltha, J.C.; Kuijpers-Jagtman, A.M. Optimum force magnitude for orthodontic tooth movement: A systematic literature review. Angle Orthod. 2003, 73, 86-92. [CrossRef] [PubMed]

54. Schröder, A.; Gubernator, J.; Nazet, U.; Spanier, G.; Jantsch, J.; Proff, P.; Kirschneck, C. Effects of sodium chloride on the gene expression profile of periodontal ligament fibroblasts during tensile strain. J. Orofac. Orthop. 2020, 81, 360-370. [CrossRef] [PubMed]

55. Garlet, T.P.; Coelho, U.; Silva, J.S.; Garlet, G.P. Cytokine expression pattern in compression and tension sides of the periodontal ligament during orthodontic tooth movement in humans. Eur. J. Oral Sci. 2007, 115, 355-362. [CrossRef] [PubMed]

56. Kirschneck, C.; Batschkus, S.; Proff, P.; Köstler, J.; Spanier, G.; Schröder, A. Valid gene expression normalization by RT-qPCR in studies on hPDL fibroblasts with focus on orthodontic tooth movement and periodontitis. Sci. Rep. 2017, 7, 14751. [CrossRef]

57. De La Zerda, A.; Kratochvil, M.J.; Suhar, N.A.; Heilshorn, S.C. Review: Bioengineering strategies to probe T cell mechanobiology. APL Bioeng. 2018, 2, 21501. [CrossRef]

58. Ma, Y.; Ji, Y.; Huang, G.; Ling, K.; Zhang, X.; Xu, F. Bioprinting 3D cell-laden hydrogel microarray for screening human periodontal ligament stem cell response to extracellular matrix. Biofabrication 2015, 7, 44105. [CrossRef] 